\title{
The relationship between psychosocial health and prenatal attachment in pregnant women
}

\author{
Nazife Bakır (iD), Şule Sarızayim \\ Bucak Health College, Burdur Mehmet Akif Ersoy University, Burdur, Turkey
}

\begin{abstract}
Objective: The aim of this study is to determine the relationship between psychosocial health and prenatal attachment in pregnant women.

Methods: This quantitative and descriptive study was conducted with 241 pregnant women who admitted to the Obstetrics and Gynecology Clinic of a state hospital in the Mediterranean Region between December 2019 and March 2020. The Introductory Characteristics Form, Prenatal Psychosocial Health Assessment Questionnaire and Prenatal Attachment Inventory were used to collect the data.

Results: It was found in the study that $84.9 \%$ of the pregnancies were planned, $83.8 \%$ of them were at the last trimester, and $31.3 \%$ of them were their first pregnancy. The mean score of pregnant women was $4.54 \pm 0.18$ (range: 3.87 to 4.87 ) in the Prenatal Psychosocial Health Assessment Questionnaire and $72.24 \pm 7.48$ (range: 50.00 to 84.00 ) in the Prenatal Attachment Inventory. It was found that the mean scores obtained in the Prenatal Psychosocial Health Assessment Questionnaire were significantly different between the groups according to age, education level, family type and number of pregnancy. There was also significant difference in the mean scores obtained in the Prenatal Attachment Inventory between the groups according to age, education level, family type, number of child and household income level.

Conclusion: We did not find any statistically significant correlation between the scores of the Prenatal Psychosocial Health Assessment Questionnaire and the Prenatal Attachment Inventory in our study.

Keywords: Pregnant woman, psychosocial health, prenatal attachment.
\end{abstract}

\section{Introduction}

The prenatal psychosocial health refers to a complete wellbeing of pregnant woman psychologically, socially and emotionally. Although women perceive pregnancy as
Özet: Gebelerde psikososyal sağlık ve doğum öncesi bağlanma arasındaki ilişki

Amaç: Bu çalışmanın amacı gebelerde psikososyal sağlık ve doğum öncesi bağlanma arasındaki ilişkiyi belirlemektir.

Yöntem: Nicel ve tanımlayıcı tipteki bu araştırma Aralık 2019 Mart 2020 arasında Akdeniz Bölgesindeki bir Devlet Hastanesinde Kadın-Doğum Polikliniğine başvuran 241 gebe ile yürütülmüştür. Veri toplamada Tanıtıcı Özellikler Formu, Gebelikte Psikososyal Sağlığı Değerlendirme Ölçeği ve Doğum Öncesi Bağlanma Ölçeği uygulanmıştır.

Bulgular: Çalışmada gebelerin \% 84.9'unun planlı gebelik olduğu, \%83.8'inin son trimesterde bulunduğu, \%31.3'ünün ilk gebeliği olduğu saptanmıştır. Gebelerin, Gebelikte Psikososyal Sağlı̆̆ı Değerlendirme Ölçeğinden aldıkları puan ortalaması $4.54 \pm 0.18$ (aralık: 3.87-4.87) ve Doğum Öncesi Bağlanma Envanterinden aldıkları puan ortalamalar1 $72.24 \pm 7.48$ (aralık: $50.00-84.00$ ) olarak belirlenmiştir. Yaş, eğitim durumu ve aile tipi, gebelik sayısına göre, gruplar arasında Gebelikte Psikososyal Sağlığı Değerlendirme Ölçeği puan ortalamalarında anlamlı fark olduğu saptanmıştır. Yine yaş, eğitim durumu ve aile tipi, çocuk sayısı ve aile gelir durumuna göre, gruplar arasında Doğum Öncesi Bağlanma Envanteri puan ortalamalarında anlamlı fark olduğu belirlenmiştir.

Sonuç: Çalışmada gebelikte Psikososyal Sağlığı Değerlendirme Ölçeği ile Doğum Öncesi Bağlanma Envanteri arasında istatistiksel anlamlı bir ilişki saptanmamıştır.

Anahtar sözcükler: Gebe, psikososyal sağlık, prenatal bağlanma.

a pleasing and exciting condition and a way to reach a certain maturity, the pregnancy makes mothers feel concerned depending on the stages of pregnancy and some psychosocial factors. ${ }^{[1,2]}$ The prenatal psychosocial health

Correspondence: Nazife Bakır, MD. Bucak Health College, Burdur Mehmet Akif Ersoy University, Burdur, Turkey. e-mail: nazbakir@hotmail.com / Received: April 19, 2020; Accepted: June 4, 2020

Please cite this article as: Bakır N, Sarızayim S. The relationship between psychosocial health and prenatal attachment in pregnant women. Perinatal Journal 2020;28(2):73-81. doi:10.2399/prn.20.0282006 
of a woman is affected by many factors such as the socioeconomic status of family, her education level, history of previous pregnancies and labor experiences, pregnancy being planned, number of child, previous and current diseases of mother, wrong and insufficient knowledge of woman about pregnancy, and low self-esteem. ${ }^{[3,4]}$ Therefore, pregnancy is a period in which it is more likely to encounter many factors that may cause anxiety and stress. It increases the likelihood of seeing depression in mother. ${ }^{[5-7]}$ Pregnant woman being healthy psychosocially is very important for maternal and fetal health. It poses a problem in terms of establishing mother-baby attachment if the psychosocial health impaired during pregnancy continues to be impaired during postnatal period..$^{[3,4]}$

Mother-baby attachment is the case where mother cares her baby through unreluctant behaviors and meets its needs in case that the baby needs the mother and where the baby have confidence in the mother. The foundations of mother-baby attachment are laid during pregnancy. Prenatal attachment represents the initial part of mother-baby attachment. The attachment between pregnant woman and fetus is the first important relationship established with the baby and it is determinative for the relationship between mother and baby after labor. ${ }^{[8,9]}$ The cases such as not having proper care during prenatal period, skipping the examinations or not going on time, consumption of alcohol, tobacco and tobacco products or other harmful substances, living in an environment where the sex of baby is considered important, miscarriage, preterm labor, undesired pregnancy and prolonged or challenging labor history are the risk factors which have a role on the impairment of psychological health during pregnancy for the development of motherhood role and the improvement of motherhood identity. These risk factors impair the psychological health of mother and hinder her motherhood duty. Addressing the motherhood and prenatal psychological experience at an early period is therefore of vital importance. ${ }^{[1]}$

The level of attachment is related with the psychological health of mother during prenatal period. The mother having a complete wellbeing psychologically is related with the good levels of psychosocial factors. In the studies carried out abroad showed that prenatal depression and high anxiety during pregnancy have a negative impact on mother-baby attachment, ${ }^{[9,1,12]}$ the significant determinative of prenatal attachment is related with prenatal and postnatal psychological health, ${ }^{[1,14]}$ and there is a significant correlation between hostile approaches of pregnant women towards fetus and mental disorders. ${ }^{[15]}$ Although there are studies carried out in Turkey which investigated psychosocial health ${ }^{[16-19]}$ and prenatal attachment levels of pregnant women ${ }^{[20-23]}$ separately, there are no sufficient studies showing the relationship between them. In this sense, we conducted our study to determine the relationship between psychosocial health and prenatal attachment of pregnant women, and we sought answers to these questions: (i) Do the introductory characteristics of pregnant women have an impact on their psychosocial health levels? (ii) Do the introductory characteristics of pregnant women have an impact on their prenatal attachment levels? (iii) Is there a relationship between the psychosocial health levels and prenatal attachment levels of pregnant women?

\section{Methods}

This quantitative and descriptive study was conducted with the pregnant women who admitted to the Obstetrics and Gynecology Clinic of a state hospital in the Mediterranean Region between December 2019 and March 2020. The population of the study comprises the pregnant women $(\mathrm{N}=651)$ who admitted to the Obstetrics and Gynecology Clinic of a state hospital in the Mediterranean Region during 2019. The sample size of the study was calculated by using the formula $\mathrm{n}=$ $\mathrm{Nt} 2 \mathrm{pq} / \mathrm{d} 2(\mathrm{~N}-1)+\mathrm{pq}$ and the minimum sample size was found 241 with $95 \%$ confidence interval and 5\% error margin. The study was completed with a total of 265 pregnant women who did not have any visual or hearing loss, spoke Turkish, open for verbal communication, completed in the questionnaire during the study period and accepted to participate in the study.

"Introductory Characteristics Form", "Prenatal Psychosocial Health Assessment Questionnaire" and "Prenatal Attachment Inventory" were applied to the pregnant women. The Introductory Characteristics Form which aims to understand the socio-demographic characteristics of the pregnant women consist of 9 questions investigating their age, education level, place of residence, family type, delivery type, gestational month, number of pregnancy, number of child and household income level.

The Prenatal Psychosocial Health Assessment Questionnaire (PPHAQ) developed by Yildız is used to evaluate the psychosocial health during pregnancy. The questionnaire includes 46 items and 6 sub-sections. The mean score is obtained by dividing the total score of the questionnaire by the number of items, and a score 
between 1 and 5 is obtained. The more the total score moves towards 1 from 5 , the more the prenatal psychosocial health is impaired, and 1 means that the psychosocial health is at the worst level. The same assessment applies to the sub-sections, and as the score moves towards 1 , it means that there is a problem related with that factor. ${ }^{[3]}$

The Prenatal Attachment Inventory (PAI) developed by Muller is used to measure the attachment levels of pregnant women to their unborn babies. ${ }^{[14]}$ The PAI was adapted to Turkish in 2013 by Duyan et al. and it has a total of 21 items aiming to measure the emotional attachment to the fetus. The participants are asked to select one of the following options for each of the statements given in the items: "Almost never $=1$ point", "Sometimes $=2$ points", "Usually = 3 points", and "Almost always". None of the statements in the inventory are not scored in a reverse way. The total score that participants may have in the inventory varies between 21 and 84, and higher scores show that the prenatal attachment level is high while lower scores show that the prenatal attachment level is low. No norm determination study was conducted regarding to the inventory, and therefore the inventory enables to make comparison between the prenatal attachment levels of the pregnant women from a different group. ${ }^{[12]}$

The data were obtained via the face-to-face interview technique by the researchers in the waiting room before the examinations of the pregnant women who visited the Obstetrics and Gynecology Clinic of a state hospital in the Mediterranean Region between December 2019 and March 2020. The aim and the methods of the study were explained to the pregnant women before their participation in the study, and it was stated that the data would be used only for scientific purposes. It took approximately 10-15 minutes to complete the questionnaire.

SPSS 20.0 (Spss Inc., Chicago, IL, USA) was used to analyze the data obtained in the study, and descriptive statistical analysis (mean, standard deviation, percentage,frequency), one-way ANOVA test, Kolmogrov Smirnov test and independent samples t-test were used. The value $\mathrm{p}<0.05$ was considered significant.

In order to conduct the study, the ethics approval was obtained from the Non-Invasive Clinical Research Ethics Committee of Burdur Mehmet Akif Ersoy University before the study. In addition, the pregnant women who participated in the study read and signed the informed consent forms, and their written and verbal consents were obtained. This study does not reflect all pregnant women in Turkey and it is only limited to the pregnant women who came to the study hospital for examination.
Table 1. The distribution of the pregnant women by the introductory characteristics.

\begin{tabular}{|c|c|c|}
\hline Introductory characteristics $(n=265)$ & $\mathbf{n}$ & $\%$ \\
\hline \multicolumn{3}{|l|}{ Age (year) } \\
\hline $15-20$ & 40 & 15.1 \\
\hline $21-28$ & 166 & 62.6 \\
\hline $29-35$ & 44 & 16.6 \\
\hline $36-42$ & 11 & 4.2 \\
\hline 43 or above & 4 & 1.5 \\
\hline \multicolumn{3}{|l|}{ Educational level } \\
\hline Primary school & 26 & 9.8 \\
\hline Secondary school & 68 & 25.7 \\
\hline High school & 117 & 44.2 \\
\hline Higher education or above & 54 & 20.3 \\
\hline \multicolumn{3}{|l|}{ Place of residence } \\
\hline City & 103 & 38.9 \\
\hline District & 135 & 50.9 \\
\hline Village & 27 & 10.2 \\
\hline \multicolumn{3}{|l|}{ Family type } \\
\hline Nuclear family & 216 & 81.5 \\
\hline Extended family & 49 & 18.5 \\
\hline \multicolumn{3}{|l|}{ Pregnancy type } \\
\hline Planned pregnancy & 225 & 84.9 \\
\hline Unplanned pregnancy & 40 & 15.1 \\
\hline \multicolumn{3}{|l|}{ Month of gestation } \\
\hline 4, 5,6 months & 43 & 16.2 \\
\hline $7,8,9$ months & 222 & 83.8 \\
\hline \multicolumn{3}{|l|}{ Number of pregnancy } \\
\hline One & 83 & 31.3 \\
\hline Two & 71 & 26.8 \\
\hline Three & 70 & 26.4 \\
\hline Four & 29 & 10.9 \\
\hline Five or more & 12 & 5.4 \\
\hline \multicolumn{3}{|l|}{ Number of child } \\
\hline None & 121 & 45.7 \\
\hline $1-2$ & 112 & 42.3 \\
\hline 3 or more & 32 & 12.0 \\
\hline \multicolumn{3}{|l|}{ Income level } \\
\hline Good & 84 & 31.7 \\
\hline Medium & 166 & 62.6 \\
\hline Low & 15 & 5.7 \\
\hline Total & 265 & 100 \\
\hline
\end{tabular}

\section{Results}

The distribution of the introductory characteristics of the pregnant women in our study are given in Table 1. Accordingly, $62.6 \%$ of the pregnant women are between 21 and 28 years old, $44.2 \%$ of them are graduated from high school, $50.9 \%$ of them reside in a district, and $81.5 \%$ of them have nuclear family. It was found that $84.9 \%$ of the pregnancies are planned, $83.8 \%$ of them are at the last trimester, $31.3 \%$ of them are the first pregnancy, $45.7 \%$ of them have no child, and the $62.6 \%$ of them have a medium income level. 
Table 2. The mean scores of the pregnant women obtained from the Prenatal Psychosocial Health Assessment Questionnaire and the Prenatal Attachment Inventory.

\begin{tabular}{lcccc} 
& Mean & Standard deviation & Minimum score & Maximum score \\
\hline Prenatal Psychosocial Health Assessment Questionnaire (PPHAQ) & 4.54 & 0.18 & 3.87 & 4.87 \\
\hline Prenatal Attachment Inventory (PAl) & 72.24 & 7.48 & 50.00 & 84.00 \\
\hline
\end{tabular}

The mean scores of the pregnant women were $4.54 \pm 0.18$ (range: 3.87 to 4.87 ) for PPHAQ and $72.24 \pm 7.48$ (range: 50.00 to 84.00 ) for PAI (Table 2).
The mean PPHAQ scores of the pregnant women according to the introductory characteristics are given in Table 3. Accordingly, the mean PPHAQ scores of those

Table 3. The mean scores of the pregnant women obtained from the Prenatal Psychosocial Health Assessment Questionnaire according to the introductory characteristics.

\begin{tabular}{|c|c|c|c|c|}
\hline \multicolumn{2}{|c|}{ Introductory characteristics $(\mathrm{n}=265)$} & \multirow[t]{2}{*}{ Mean } & \multirow[t]{2}{*}{ Standard deviation } & \multirow[t]{2}{*}{$\begin{array}{c}\text { Test statistics } \\
\text { p-value } \\
\text { Significant difference }\end{array}$} \\
\hline \multicolumn{2}{|l|}{ Age (year)* } & & & \\
\hline $15-20$ & $a$ & 4.53 & 0.17 & 0.537 \\
\hline $21-28$ & b & 4.56 & 0.17 & 0.002 \\
\hline $29-35$ & c & 4.48 & 0.17 & $a>d, e ; b>c, d, e$ \\
\hline $36-42$ & $d$ & 4.40 & 0.15 & \\
\hline 43 or above & e & 4.40 & 0.15 & \\
\hline \multicolumn{5}{|l|}{ Educational level* } \\
\hline Primary school & a & 4.45 & 0.22 & 3.521 \\
\hline Secondary school & $\mathrm{b}$ & 4.54 & 0.16 & 0.016 \\
\hline High school & c & 4.52 & 0.18 & $b>a ; d>c, a$ \\
\hline Higher education or above & $d$ & 4.59 & 0.15 & \\
\hline \multicolumn{5}{|l|}{ Place of residence* } \\
\hline City & & 4.53 & 0.15 & 2.411 \\
\hline District & & 4.56 & 0.18 & 0.092 \\
\hline Village & & 4.49 & 0.26 & \\
\hline \multicolumn{5}{|l|}{ Family type $^{\dagger}$} \\
\hline Nuclear family & & 4.55 & 0.17 & 0.110 \\
\hline Extended family & & 4.47 & 0.18 & 0.005 \\
\hline \multicolumn{5}{|l|}{ Pregnancy type $^{\dagger}$} \\
\hline Planned pregnancy & & 4.56 & 0.16 & 2.448 \\
\hline Unplanned pregnancy & & 4.38 & 0.18 & 0.000 \\
\hline \multicolumn{5}{|l|}{ Month of gestation ${ }^{\dagger}$} \\
\hline 4, 5, 6 months & & 4.53 & 0.18 & 1.185 \\
\hline $7,8,9$ months & & 4.54 & 0.17 & 0.905 \\
\hline \multicolumn{5}{|l|}{ Number of pregnancy* } \\
\hline One & a & 4.53 & 0.15 & 0.472 \\
\hline Two & b & 4.52 & 0.20 & 0.005 \\
\hline Three & c & 4.59 & 0.17 & $c>a, b, d, e$ \\
\hline Four & d & 4.48 & 0.15 & \\
\hline Five or more & e & 4.42 & 0.16 & \\
\hline \multicolumn{5}{|l|}{ Number of child* } \\
\hline None & a & 4.53 & 0.17 & 0.220 \\
\hline $1-2$ & $b$ & 4.56 & 0.19 & 0.034 \\
\hline 3 or more & c & 4.48 & 0.16 & $b>c$ \\
\hline \multicolumn{5}{|l|}{ Income level* } \\
\hline Good & a & 4.56 & 0.15 & 0.203 \\
\hline Medium & $\mathrm{b}$ & 4.52 & 0.18 & 0.044 \\
\hline Low & c & 4.61 & 0.25 & $a>b$ \\
\hline
\end{tabular}

*One-way ANOVA; 'Independent samples t-test. 
in 21-28 age range were significantly higher than those who are 29 years old or above, and the mean PPHAQ scores of those in 15-20 age range were significantly higher than those who are 36 years old or above. The mean PPHAQ scores of those graduated from secondary school were significantly higher than those graduated from primary school, and the mean PPHAQ scores of those with higher education levels were significantly higher than those graduated from primary school and high school. It was found that the mean PPHAQ scores of those who have nuclear family were higher than those who have extended family, and the mean PPHAQ scores of those with planned pregnancy were higher than those with unplanned pregnancy, which were all statistically significant. It was also found that the mean PPHAQ scores of those with three pregnancies were higher than those with other numbers of pregnancy, and the mean PPHAQ scores of those with high level of household income were higher than those with medium level of household income, which were all statistically significant.

Table 4. The mean scores of the pregnant women obtained from the Prenatal Attachment Inventory according to the introductory characteristics.

\begin{tabular}{|c|c|c|c|c|}
\hline \multicolumn{2}{|c|}{ Introductory characteristics $(n=265)$} & Mean & Standard deviation & $\begin{array}{c}\text { Test statistics } \\
\text { p-value } \\
\text { Significant difference }\end{array}$ \\
\hline \multicolumn{5}{|l|}{ Age (year)* } \\
\hline $15-20$ & a & 76.17 & 4.39 & 5.323 \\
\hline $21-28$ & $b$ & 71.33 & 7.32 & 0.000 \\
\hline 29-35 & c & 72.90 & 8.15 & $a, e>b, c, d$ \\
\hline $36-42$ & $d$ & 67.45 & 10.86 & \\
\hline 43 or above & e & 77.00 & 0.81 & \\
\hline \multicolumn{5}{|l|}{ Educational level* } \\
\hline Primary school & a & 76.26 & 6.18 & 3.401 \\
\hline Secondary school & $\mathrm{b}$ & 70.83 & 7.94 & 0.018 \\
\hline High school & $c$ & 72.19 & 7.53 & $a>b, c, d$ \\
\hline Higher education or above & d & 72.20 & 6,81 & \\
\hline \multicolumn{5}{|l|}{ Place of residence* } \\
\hline City & & 72.31 & 7.45 & 0.176 \\
\hline District & & 71.99 & 7.12 & 0.839 \\
\hline Village & & 72.92 & 9.05 & \\
\hline \multicolumn{5}{|l|}{ Family type $^{\dagger}$} \\
\hline Nuclear family & & 72.94 & 7.24 & 1.948 \\
\hline Extended family & & 69.16 & 7.82 & 0.001 \\
\hline \multicolumn{5}{|l|}{ Pregnancy type $^{\dagger}$} \\
\hline Planned pregnancy & & 72.53 & 7.36 & 1.742 \\
\hline Unplanned pregnancy & & 70.65 & 8.00 & 0.143 \\
\hline \multicolumn{5}{|l|}{ Month of gestation ${ }^{\dagger}$} \\
\hline 4, 5, 6 months & & 72.51 & 7.44 & 0.102 \\
\hline $7,8,9$ months & & 72.19 & 7.50 & 0.802 \\
\hline \multicolumn{5}{|l|}{ Number of pregnancy* } \\
\hline One & a & 73.21 & 6.17 & 1.319 \\
\hline Two & $b$ & 72.52 & 7.04 & 0.263 \\
\hline Three & $c$ & 72.12 & 8.35 & \\
\hline Four & $d$ & 69.75 & 8.15 & \\
\hline Five or more & $\mathrm{e}$ & 70.66 & 10.44 & \\
\hline \multicolumn{5}{|l|}{ Number of child* } \\
\hline None & a & 73.14 & 6.40 & 3.452 \\
\hline $1-2$ & $b$ & 72.13 & 7.85 & 0.033 \\
\hline 3 or more & $\mathrm{C}$ & 69.28 & 9.20 & $a>c$ \\
\hline \multicolumn{5}{|l|}{ Income level* } \\
\hline Good & a & 71.11 & 8.27 & 4.560 \\
\hline Medium & $b$ & 72.36 & 7.14 & 0.011 \\
\hline Low & $\mathrm{C}$ & 77.33 & 8.27 & $c>a, b$ \\
\hline
\end{tabular}

*One-way ANOVA; 'Independent samples t-test. 
The mean PAI scores of the pregnant women according to the introductory characteristics are given in Table 4. Accordingly, the mean PAI scores of those in 15-20 age range and those who are 43 years old or above were significantly higher than those in other age groups in a statistically significant way. The mean PAI scores of those graduated from primary school were higher than those with other educational levels in a statistically significant way. It was found that the mean PAI scores of those who have nuclear family were higher than those who have extended family, and the mean PAI scores of those with no child were higher than those with 3 or more children, which were all statistically significant. Also, the mean PAI scores of those with low level of household income were higher than those with medium and high levels of household income in a statistically significant way. There was no statistically significant relationship between PPHAQ and PAI scores of the pregnant women (Table 5).

\section{Discussion}

In our study, the mean PPHAQ score of the pregnant women was $4.54 \pm 0.18$ (range: 3.87 to 4.87 ). Aksay et al. reported in their study that the pregnant women had a medium level of psychosocial health and their mean PPHAQ score was $3.13 \pm 0.33 .{ }^{[16]}$ Yildiz reported that the mean PPHAQ score of the pregnant women was $3.84 \pm 0.51$ and they had a medium level of psychosocial health. ${ }^{[1]}$ In the study of Özşahin et al., this mean score was $3.20 \pm 0.50$ and the level of psychosocial health was medium. ${ }^{[17]}$ The level of psychosocial health was medium in relevant studies, but it was at a high level in our study. In parallel with our study, Koyuncu reported in their study that the mean PPHAQ score was $3.95 \pm 0.45$ and the level of psychosocial health was high. ${ }^{[18]}$ In the study of Değirmenci, the mean PPHAQ score was $4.02 \pm 0.41$ and the level of psychosocial health was high. ${ }^{[19]}$ In the

Table 5. The correlation between the scores of the pregnant women obtained from the Prenatal Psychosocial Health Assessment Questionnaire and the Prenatal Attachment Inventory. *

\begin{tabular}{lcc} 
& $\begin{array}{c}\text { Prenatal Psychosocial } \\
\text { Health Assessment } \\
\text { Questionnaire (PPHAQ) }\end{array}$ \\
\hline $\begin{array}{l}\text { Prenatal Attachment } \\
\text { Inventory (PAI) }\end{array}$ & $\mathrm{p}$ & 0.072 \\
\hline
\end{tabular}

*Pearson correlation. study of Derya et al., the psychosocial health level of the pregnant women was high with a mean PPHAQ score of 4.0 $\pm 0.4 .{ }^{[24]}$ We believe that the high psychosocial health levels in our study may be associated with the high rate of planned pregnancies $(84.9 \%)$ of the women who participate in our study. We consider that the high rate of planned pregnancies may show that the number of women who are ready for pregnancy psychologically is high and being ready psychologically for pregnancy may affect psychosocial health positively.

In our study, we found that the mean PPHAQ scores of those graduated from secondary school were higher than those graduated from primary school, and the mean PPHAQ scores of those with higher education levels were significantly higher than those graduated from primary school and high school in a statistically significant way. Similar to our study, Özşahin et al. found that the mean PPHAQ scores of those graduated from primary school were significantly lower than those graduated from secondary school, high school and university. ${ }^{[17]}$ Değirmenci did not found any significant difference between educational levels and mean PPHAQ scores. ${ }^{[19]}$ The pregnancy is a period during which women most frequently benefit from the healthcare services and are more open to learn health related information and behaviors. In the study of Filiz, the authors reported a positive correlation between health perception and health literacy. ${ }^{[25]}$ Also, some studies in the literature emphasize that the health literacy level increases as educational levels increase. ${ }^{[26]}$ We consider that the difference in psychosocial health levels according to the educational levels in our study may be associated with health literacy.

We found in our study that the mean PPHAQ scores of those with planned pregnancy were higher than those with the unplanned pregnancy, which was statistically significant. Özşahin et al. did not find a significant difference between the mean PPHAQ scores of those with planned pregnancy and those with the unplanned pregnancy. ${ }^{[17]}$ We consider that the woman being in control of the pregnancy planning shows the readiness of woman for the pregnancy and therefore the stress during pregnancy will decrease and their psychosocial health will be affected positively.

We found in our study that the mean PPHAQ scores of those with high level of household income were higher than those with medium level of household income, which is statistically significant. The studies in the liter- 
ature show that there is a positive correlation between the psychosocial health and high level of household income. Koyuncu reported in their study that the mean PPHAQ scores of those perceiving their income level high are significantly higher than the other groups. ${ }^{[18]}$ Degirmenci found in their study that the mean PPHAQ scores of those with lower income than their expenses were significantly lower than the other groups. ${ }^{[19]}$ In a study performed, it was found that the depression symptoms are more common in women with low socio-economic levels. ${ }^{[27]}$ The authors believed that there is a correlation with income level and the care of baby and preparing for future, and this may affect the psychosocial health of mother.

The prenatal attachment is a term used to define the emotional bond which is established between woman and fetus during pregnancy and exists emotionally, cognitively and behaviorally. ${ }^{[28]}$ Maternal age is also among the factors affecting mother-baby attachment. ${ }^{[9]}$ We found in our study that the mean PAI scores of those in 15-20 age range and who are 43 years old or above are higher than those in other age groups in a statistically significant way. In a study conducted on pregnant women with high risk, the authors reported that the median PAI scores of the pregnant women between 18 and 30 years old were higher than those who are 31 years old or above in a statistically significant way. ${ }^{[20]}$ Hjelmstedt et al. found that the PAI scores of young mothers are higher. ${ }^{[2]}$ Damato also reported that the prenatal attachment level is higher in young pregnant women. ${ }^{[30]}$ Özkan et al. found in their study that the mean PAI scores of women who are 31 years old or above are significantly higher than those who are between 18 and 30 years old. ${ }^{[21]}$ The studies conducted on various sample groups show that there is a correlation between age and prenatal attachment.

We found in our study that the mean PAI scores of those graduated from primary school were higher than those with other educational levels in a statistically significant way. Bakır et al. reported in their study that the median PAI scores of those graduated from secondary school or with higher education levels were higher than those graduated from primary school in a statistically significant way. ${ }^{[20]}$ In the study of Küçükkaya et al., the authors found that the prenatal attachment level of those graduated from high school or with higher education levels was significantly higher than those graduated from primary school or with lower education levels. ${ }^{[23]}$ While these two studies are not similar to our study, Özkan et al. reported in their study similar to our study that the prenatal attachment level of the pregnant women graduated from primary school was higher than the other pregnant women. ${ }^{[21]}$ The studies conducted show that the educational level affects prenatal attachment differently.

We found in our study that the mean PAI scores of those who have nuclear family were higher than those who have extended family in a statistically significant way. Although it was not statistically significant, Bakır et al. reported in their study that the median PAI scores of the pregnant women who have nuclear family are higher than those who have extended family. ${ }^{[20]}$

In our study, we found that the mean PAI scores of those who have no child were higher than those with 3 or more children in a statistically significant way. Bakır et al. reported in their study that the median PAI scores of those with no child were higher than the pregnant women with one or more children in a statistically significant way. ${ }^{[20]}$ It can be said that the women without any child are more willing to have a child, and therefore their prenatal attachment levels are higher.

In our study, we found that the mean PAI scores of those with low level of household income were higher than those with medium and high levels of household income in a statistically significant way. Unlike our study, Elkin reported in their study that the median PAI scores of those whose incomes are higher than their expenses were significantly higher than those with other income levels. ${ }^{[2]}$ Küçükkaya et al. also found in their study that the prenatal attachment level of those whose incomes are higher than or equal to their expenses were higher than those whose incomes are lower than their expenses. ${ }^{[23]}$ While the results of these two studies are not in parallel with our study, Damato reported similar to our study that the prenatal attachment level of those with low income level was higher. ${ }^{[30]}$

Mental and emotional conditions of a pregnant woman affect the course of pregnancy. Biological and psychological changes during pregnancy and labor may decrease the prenatal attachment level by affecting psychosocial health negatively. Feelings such as worry, nervousness and self-depreciation may prevent pregnant women to establish attachment with fetus. ${ }^{[28]}$ In a study investigating the pregnant women dealing with stress, depression and prenatal attachment levels and the factors affecting them, the authors found that the pregnant women with low economic levels, low educational levels and who consider to terminate pregnancy 
show more depression symptoms, but there is no statistically significant difference between them and attachment levels. ${ }^{[31]}$ We did not find any statistically significant correlation between PPHAQ and PAI scores in our study.

\section{Conclusion}

In our study, we found statistically significant difference between PPHAQ scores in terms of age, educational level, family type, number of pregnancy and household income level. We also found statistically significant difference between PAI scores in terms of age, educational level, family type, number of child and household income level. On the other hand, there was no statistically significant correlation between PPHAQ and PAI scores. In terms of the limitations of our study, the study population reflects the pregnant women who participated in our study only from a single hospital, we recommend to conduct further studies with pregnant women from different regions to investigate the correlation between psychosocial health and prenatal attachment level. Also, we recommend healthcare professionals help pregnant women to express themselves in the best way and identify current problems through therapeutic communication to be established with them considering that fact that various factors affect the psychosocial health and prenatal attachment levels of pregnant women. In addition, we recommend organizing multidisciplinary trainings in order to eliminate the problems regarding psychosocial health and prenatal attachment levels and to improve health.

Conflicts of Interest: No conflicts declared.

\section{References}

1. Yıldız H. Gebelikte psikososyal sağlı̆ğ değerlendirme ölçeği geliştirme çalışması. Maltepe Üniversitesi Hemşirelik Bilim ve Sanatı Dergisi 2011;4:63-74.

2. Kuğu N, Akyüz G. Gebelikte ruhsal durum. Cumhuriyet Üniversitesi Tıp Fakültesi Dergisi 2001;23:61-4.

3. Körükcü Ö, Deliktaş A, Aydın R, Kabukcuoğlu K. Gebelikte psikososyal să̆lık durumu ile doğum korkusu arasındaki ilişkinin incelenmesi. Clinical and Experimental Health Sciences 2017;7:159-65. [CrossRef]

4. Boybay KS, Dereli YS. Son trimester nullipar gebelerde bazı sosyo-demografik ve obstetrik özelliklerin psikososyal sağlık düzeyine etkisi. Ege Üniversitesi Hemşirelik Fakültesi Dergisi 2015;31:53-66.
5. Vırıt O, Akbaş E, Savaş HA, Sertbaş G, Kandemir H. Gebelikte depresyon ve kaygı düzeylerinin sosyal destek ile ilişkisi. Nöropsikiyatri Arşivi 2008;45:9-13.

6. Yeşilçiçek Çalık K, Aktaş S. Gebelikte depresyon: sıklık, risk faktörleri ve tedavisi. Psikiyatride Güncel Yaklaşımlar 2011;3: 142-62.

7. Yeşiltepe Oskay Ü. Yüksek riskli gebelerde hemşirelik bakımı. Perinatoloji Dergisi 2004;12:11-6.

8. Duyan V, Gül Kapısız S, Yakut Hİ. Doğum Öncesi Bağlanma Envanteri'nin bir grup gebe üzerinde Türkçe'ye uyarlama çalışması. The Journal of Gynecology, Obstetrics and Neonatology 2013;10:1609-14.

9. Abasi E, Tahmasebi H, Zafari M, Nasiri Takami G. Assessment on effective factors of maternal-fetal attachment in pregnant women. Life Science Journal 2012;9(S1):68-75. [CrossRef]

10. Muller ME. Development of the prenatal attachment inventory. West J Nurs Res 1993;15:199-211. [PubMed] [CrossRef]

11. Flykt M, Kanninen K, Sinkkonen J, Punamäki RL. Maternal depression and dyadic interaction: the role of maternal attachment style. Infant and Child Development 2010;19:530-50. [CrossRef]

12. Lindgren K. Relationships among maternal-fetal attachment, prenatal depression, and health practices in pregnancy. Res Nurs Health 2001;24:203-17. [PubMed] [CrossRef]

13. Walsh J, Hepper EG, Bagge SR., Wadephul F, Jomeen J. Maternal-fetal relationships and psychological health: emerging research directions. Journal of Reproductive and Infant Psychology 2013;31:490-9. [CrossRef]

14. Walsh J, Hepper EG, Marshall BJ. Investigating attachment, care giving, and mental health: a model of maternal-fetal relationships. BMC Pregnancy Childbirth 2014;14:383. [PubMed] [CrossRef]

15. Berlin LJ, Dodge KA, Reznick JS. Examining pregnant women's hostile attributions about infants as a predictor of offspring maltreatment. JAMA Pediatr 2013;167:549-53. [PubMed] [CrossRef]

16. Aksay Y, Gülhan YB, Saygın N, Körükcü Ö. Gebelerin psikososyal sağlıkları doğum tercihini etkiler mi? Gümüşhane Üniversitesi Sağlık Bilimleri Dergisi 2017;6:138-45.

17. Özşahin Z, Erdemoğlu Ç, Karakayalı Ç. Gebelikte psikososyal sağlık düzeyi ve ilişkili faktörler, The Journal of Turkish Family Physician 2018;9:34-46. [CrossRef]

18. Koyuncu SB. Son trimester nullipar gebelerde bazı sosyodemografik ve obstetrik özelliklerin psikososyal sağlık düzeyine etkisi. Yüksek lisans tezi, Selçuk Üniversitesi Sağlık Bilimleri Enstitüsü Hemşirelik Anabilim Dalı, Konya, 2013.

19. Değirmenci F. Gebelerin psikososyal sağlık durumları ile sosyal destekleri arasındaki ilişki, Yüksek lisans tezi, Mersin Üniversitesi Sağlık Bilimleri Enstitüsü Hemşirelik Anabilim Dalı, Mersin, 2016.

20. Bakır N, Ölçer Z, Oskay Ü. Yüksek riskli gebelerin prenatal bağlanma düzeyi ve etkileyen faktörler. Uluslararası Hakemli Kadın Hastalıkları ve Anne Çocuk Sağlı̆̆ı Dergisi 2014;1:2637. 
21. Özkan TK, Küçükkelepçe DŞ, Özkan SA. Gebelikte prenatal bağlanma ve vücut algısı arasındaki ilişki ve etkileyen faktörler. Celal Bayar Üniversitesi Sağlık Bilimleri Enstitüsü Dergisi 2020;7:49-54. [CrossRef]

22. Elkin N. Gebelerin prenatal bağlanma düzeyleri ve bunları etkileyen faktörler. Sürekli Tip Eğitimi Dergisi 2015;24:230-6.

23. Küçükkaya B, Kahyaoğlu Süt H, Öz S, Altan Sarıkaya N. Gebelik döneminde çiftler arası uyum ve prenatal bağlanma arasındaki ilişki. Acıbadem Üniversitesi Sağlık Bilimleri Dergisi 2020;11:102-10. [CrossRef]

24. Derya YA, Özşahin Z, Uçar T, Erdemoğlu Ç, Ünver H. Gebelikteki yakınmaların yaşam kalitesine etkisi ile psikososyal sağlık düzeyi arasındaki ilişkinin incelenmesi. Turkish Journal of Family Medicine and Primary Care 2018;12:171-7. [CrossRef]

25. Filiz E. Sağlık okuryazarlığının gebelik ve sağlık algısı ile ilişkisi. Doktora tezi, Selçuk Üniversitesi Sağlık Bilimleri Enstitüsü Halk Sağlı̆̆ı Anabilim Dalı Konya, 2015.

26. Safeer RS, Keenan J. Health literacy: the gap between physicians and patients. Am Fam Physician 2005;72:463-8. [PubMed]
27. Seguin L, St-Denis M, Loiselle J. Cronic stressors, social support and depression during pregnancy. Obstet Gynecol 1995; 85:583-8. [PubMed] [CrossRef]

28. Bekmezci H, Özkan H. Gebelikte psikososyal sağlık bakım, prenatal bağlanma ve ebe-hemşirenin sorumlulukları. Uluslararası Hakemli Kadın Hastalıkları ve Anne Çocuk Sağlığı Dergisi (JACSD) 2016;3:50-62. [CrossRef]

29. Hjelmstedt A, Widstrom AM, Collins A. Psychological correlates of prenatal attachment in women who conceived after in vitro fertilization and women who conceived naturally. Birth 2006;33:303-10. [PubMed] [CrossRef]

30. Damato EG. Predictors of prenatal attachment in mothers of twins. J Obstet Gynecol Neonatal Nurs 2004;33:436-45. [PubMed] [CrossRef]

31. Yılmaz SD, Beji NK. Gebelerin stresle başa çıkma, depresyon ve prenatal bağlanma düzeyleri ve bunları etkileyen faktörler. Genel Tip Dergisi 2010;20:99-108.

Bu makalenin kullanım izni Creative Commons Attribution-NoCommercial-NoDerivs 3.0 Unported (CC BY-NC-ND3.0) lisansı aracılı̆̆ıyla bedelsiz sunulmaktadır. / This work is licensed under the Creative Commons Attribution-NonCommercial-NoDerivs 3.0 Unported (CC BY-NC-ND3.0) License. To view a copy of this license, visit http://creativecommons.org/licenses/by-nc-nd/3.0/ or send a letter to Creative Commons, PO Box 1866, Mountain View, CA 94042, USA. 